\title{
Desulfurispora thermophila gen. nov., sp. nov., a thermophilic, spore-forming sulfate-reducer isolated from a sulfidogenic fluidized-bed reactor
}

Correspondence

Anna H. Kaksonen

anna.kaksonen@tut.fi

\author{
Anna H. Kaksonen, ${ }^{1}$ Stefan Spring, ${ }^{2}$ Peter Schumann, ${ }^{2}$ \\ Reiner M. Kroppenstedt ${ }^{2}$ and Jaakko A. Puhakka ${ }^{1}$ \\ ${ }^{1}$ Institute of Environmental Engineering and Biotechnology, Tampere University of Technology,
Tampere, Finland \\ ${ }^{2} \mathrm{DSMZ}$ - German Collection of Microorganisms and Cell Cultures, Braunschweig, Germany
}

\begin{abstract}
A thermophilic, Gram-positive, endospore-forming, sulfate-reducing bacterium was isolated from a sulfidogenic fluidized-bed reactor treating acidic metal- and sulfate-containing water. The strain, designated RA50E $1^{\top}$, was rod-shaped and motile. The strain grew at $40-67^{\circ} \mathrm{C}$ (optimum growth at $59-61^{\circ} \mathrm{C}$ ) and $\mathrm{pH}$ 6.4-7.9 (optimum growth at $\mathrm{pH} 7.0-7.3$ ). The strain tolerated up to $1 \%$ $\mathrm{NaCl}$. Sulfate, sulfite, thiosulfate and elemental sulfur were used as electron acceptors, but not nitrate, nitrite or iron(III). Electron donors utilized were $\mathrm{H}_{2} / \mathrm{CO}_{2}(80: 20$, v/v), alcohols, various carboxylic acids and some sugars. Fermentative growth occurred on lactate and pyruvate. The cell wall contained meso-diaminopimelic acid and the major respiratory isoprenoid quinone was

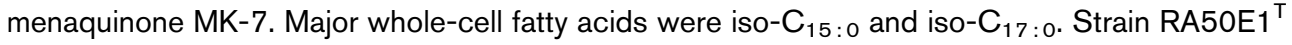
was distantly related to representatives of the genera Desulfotomaculum, Pelotomaculum, Sporotomaculum and Cryptanaerobacter. On the basis of 16S rRNA gene sequence data, the strain cannot be assigned to any known genus. Based on the phenotypic and phylogenetic features of strain RA50E $1^{\top}$, it is proposed that the strain represents a novel species in a new genus, for which the name Desulfurispora thermophila gen. nov., sp. nov. is proposed. The type strain of Desulfurispora thermophila is RA50E1 ${ }^{\top}\left(=\mathrm{DSM} 16022^{\top}=\mathrm{JCM} 14018^{\top}\right)$.
\end{abstract}

The previously described thermophilic sulfate-reducing bacteria (SRB) have been classified within the genera Desulfotomaculum (Campbell \& Postgate, 1965), Thermodesulfobacterium (Zeikus et al., 1983), Thermodesulfovibrio (Henry et al., 1994), Thermodesulforhabdus (Beeder et al., 1995), Thermodesulfobium (Mori et al., 2003), Thermodesulfatator (Moussard et al., 2004) and Desulfovirgula (Kaksonen et al., 2007). Spore-forming SRB include members of the genera Desulfotomaculum (Campbell \& Postgate, 1965), Desulfosporosinus (Stackebrandt et al., 1997), 'Desulfosporomusa' (Sass et al., 2004) and Desulfovirgula (Kaksonen et al., 2007). Recently, SRB have been isolated from sulfidogenic fluidized-bed reactors (FBR) treating acidic metal-containing wastewater (Kaksonen et al., 2004c). This paper describes one of the isolates, a novel thermophilic spore-forming SRB, strain RA50E1 $1^{\mathrm{T}}$.

Strain RA50E1 ${ }^{\mathrm{T}}$ was isolated from a sulfidogenic laboratoryscale FBR after over 600 days of continuous flow operation

Abbreviations: DMA, dimethyl acetal; FBR, fluidized-bed reactor; SRB, sulfate-reducing bacteria.

The GenBank/EMBL/DDBJ accession number for the 16S rRNA gene sequence of strain RA50E $1^{\top}$ is $A Y 548776$. at $35^{\circ} \mathrm{C}$ (Kaksonen et al., 2004c). The FBR had been inoculated with enrichment cultures originating from methanogenic granular sludge (Neson Oy, Jokioinen, Finland) and sediments from Outokumpu's Pyhäsalmi mine, Finland (Kaksonen et al., 2003b). The performance and microbiology of the FBR has been described previously (Kaksonen et al., 2003a, b, 2004a, b, c). The isolation of strain RA50E1 ${ }^{\mathrm{T}}$ was performed at $50{ }^{\circ} \mathrm{C}$ using modified Postgate growth medium ( $\mathrm{pH} 7.0-7.5)$ (Kaksonen et al., 2004c) and anaerobic roll-tubes solidified with $1.5 \%$ agar. For chemotaxonomic analysis and DNA isolation, the strain was cultured at $50{ }^{\circ} \mathrm{C}$ in modified DSM medium 641 containing lactate as electron donor. The medium was supplemented with $1 \mathrm{ml}$ selenate-tungstate solution (DSM medium 385) $1^{-1}$ and sodium dithionate $\left(25 \mathrm{mg} \mathrm{l}^{-1}\right)$ was used as the reducing agent instead of $\mathrm{Na}_{2} \mathrm{~S}$.

The isolate was examined by phase-contrast microscopy (Zeiss Axioskop 2) and photomicrographs were obtained using the agar slide technique as described previously (Kaksonen et al., 2004c). Flagellum staining was performed as described by Heimbrook et al. (1989) and cells were examined for flagella using an Axiophot light microscope (Zeiss). Spore formation by the strain was determined 
microscopically and by testing for growth after heat treatment $\left(80^{\circ} \mathrm{C}\right.$ for $\left.20 \mathrm{~min}\right)$. The Gram type of the cells was determined by both Gram staining and the $\mathrm{KOH}$ test (Gregersen, 1978).

The effects of temperature, $\mathrm{pH}$ and $\mathrm{NaCl}$ concentration on growth were determined as described previously using lactate as electron donor in modified DSM medium 641 (Kaksonen et al., 2006a). The ability of the strain to utilize various electron donors $(1-20 \mathrm{mM})$ was tested in a medium containing $20 \mathrm{mM}$ sulfate. The utilization of various electron acceptors $(10 \mathrm{mM})$ was studied using lactate $(10 \mathrm{mM})$ as electron donor. Amorphous iron(III) oxyhydroxide was formed by neutralizing $\mathrm{FeCl}_{3}$ solution to $\mathrm{pH} 7$ with $\mathrm{NaOH}$. The cultures were incubated for 1-2 weeks. Electron donor utilization was assessed by bacterial growth (OD at $660 \mathrm{~nm}$; Shimadzu UV-1601 spectrophotometer or Ultrospec II LKB Biochrom 4050 UV/visible spectrophotometer), hydrogen sulfide production or substrate conversion. Hydrogen sulfide production was determined spectrophotometrically and substrate conversion was determined by GC as described previously (Kaksonen et al., 2004c). Ferrous iron was determined colorimetrically (Shimadzu UV-1601) with ferrozine (Stookey, 1970). Concentrations of sulfate, sulfite, thiosulfate, nitrate and nitrite were determined by ion chromatography (Dionex DX-120).

Diaminopimelic acid isomers were detected in cell-wall hydrolysates by TLC as described previously (Rhuland et al., 1955; Kaksonen et al., 2006b). Respiratory isoprenoid quinones were extracted and analysed according to the methods described by Collins \& Jones (1981), Monciardini et al. (2003) and Groth et al. (1996) by using HPLC and electron impact MS (Kaksonen et al., 2006b). Methyl esters of cellular fatty acids were obtained by saponification, methylation, extraction and base wash, as described previously (Kämpfer \& Kroppenstedt, 1996; Kroppenstedt, 1985; Miller, 1982). The fatty acid methyl ester mixtures were separated by GC (Hewlett Packard 5890 Series II) as described previously (Kaksonen et al., 2006b).

For 16S rRNA gene sequencing, cells were pelleted from $1.5 \mathrm{ml}$ liquid culture at $10000 \mathrm{~g}$ for $1 \mathrm{~min}$, washed with PBS (7.2 mM Na $2 \mathrm{HPO}_{4}, 2.8 \mathrm{mM} \mathrm{NaH} \mathrm{PO}_{4}, 130 \mathrm{mM} \mathrm{NaCl}$, $\mathrm{pH}$ 7.2) and resuspended in $50 \mu \mathrm{l}$ PBS. 16S rRNA genes were amplified by direct lysis PCR using primers $27 \mathrm{~F}$ and 1492R (Kaksonen et al., 2004c). The reaction mixtures contained $25 \mu \mathrm{l}$ HotStarTaq master mix (Qiagen), $1 \mu \mathrm{M}$ each of both primers, $1 \mu \mathrm{l}$ cell suspension and $23 \mu \mathrm{l}$ sterile distilled water. Thermal cycling was carried out with a Minicycler (MJ Research) as follows: initial denaturation and activation of HotStarTaq at $95^{\circ} \mathrm{C}$ for $15 \mathrm{~min}$ followed by 30 cycles of denaturation at $94^{\circ} \mathrm{C}$ for $1 \mathrm{~min}$, primer annealing at $50^{\circ} \mathrm{C}$ for $2 \mathrm{~min}$ and primer extension at $72^{\circ} \mathrm{C}$ for $2 \mathrm{~min}$, and final extension at $72^{\circ} \mathrm{C}$ for $10 \mathrm{~min}$. PCR products were purified with a QIAquick PCR Purification kit (Qiagen) and visualized by gel electrophoresis using ethidium-bromide-stained $\left(0.2 \mathrm{mg} \mathrm{l}^{-1}\right) 1 \%$ agarose gels.
The 16S rRNA genes were sequenced using primers 27F, 518R, 704F, 787R, 1100R and 1241F (Kaksonen et al., 2004c) in separate sequencing reactions. Sequencing was performed using the ABI PRISM Big-Dye Terminator Ready Reaction kit on an ABI 373 automated sequencer or on an ABI Prism 3100 Genetic Analyzer (Applied Biosystems) operated by the Australian Neuromuscular Research Institute (ANRI) or Royal Perth Hospital DNA sequencing service. The DNA sequence chromatograms were analysed and single primer sequences were compiled using the BioEdit sequence alignment editor (http://www.mbio.ncsu.edu/BioEdit/bioedit. html). Phylogenetic affiliations of the sequences were estimated initially using the program BLAST (http://www.ncbi. nlm.nih.gov/blast/) (Altschul et al., 1990). A phylogenetic tree of the 16S rRNA gene sequence of strain RA50E $1^{\mathrm{T}}$ (1545 bp between Escherichia coli positions 28 and 1491) and related species was constructed using distance matrix and neighbour-joining methods in ARB. The robustness of the phylogeny was tested by bootstrap analysis with 1000 iterations.

Genomic DNA for $\mathrm{G}+\mathrm{C}$ content determination was released by rupturing cells using a French pressure cell (Thermo Spectronic) followed by chromatographic purification on hydroxyapatite (Cashion et al., 1977). The DNA was hydrolysed with P1 nuclease and the nucleotides were dephosphorylated with bovine alkaline phosphatase (Mesbah et al., 1989). The G $+\mathrm{C}$ content of the resulting deoxyribonucleosides was determined by reversed-phase HPLC (Shimadzu) and calculated from the $\mathrm{dG}$ : dT ratio (Tamaoka \& Komagata, 1984; Mesbah et al., 1989).

Cells of strain RA50E $1^{\mathrm{T}}$ were straight or slightly curved rods, $0.6-1.0 \mu \mathrm{m}$ in diameter and 2.0-9.0 $\mu \mathrm{m}$ in length (Fig. 1). The size of the cells was dependent on growth medium and temperature. The strain formed oval spores, which were able to germinate after a heat shock. Spores were located centrally or subterminally. Sporulation did not cause significant swelling of the cells. Cells were motile with two or more

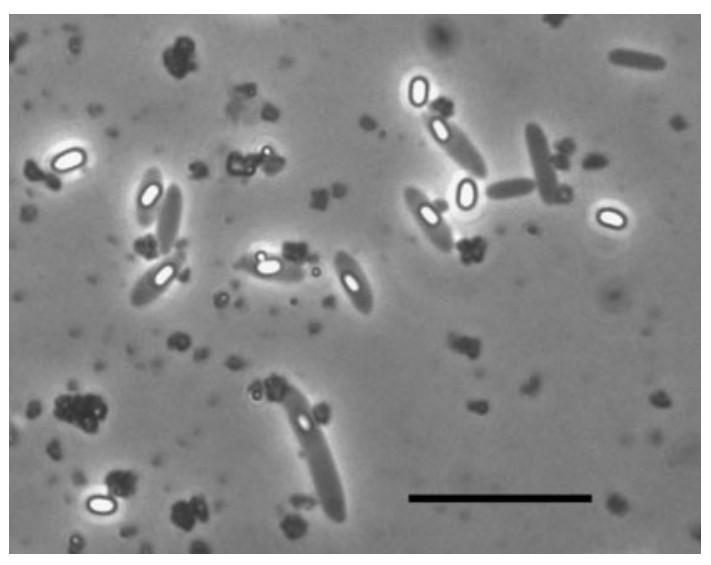

Fig. 1. Phase-contrast micrograph of cells of strain RA50E1 $1^{\top}$. Bar, $10 \mu \mathrm{m}$. 
Table 1. Characteristics of strain $\mathrm{RA} 50 \mathrm{E} 1^{\top}$ and some of its closest sulfate-reducing relatives

Strains: 1, RA50E1 ${ }^{\mathrm{T}}$; 2, Desulfotomaculum thermocisternum ST90 ${ }^{\mathrm{T}}$ (unless indicated, data from Nilsen et al., 1996); 3, Pelotomaculum thermopropionicum $\mathrm{SI}^{\mathrm{T}}$ (Imachi et al., 2002); 4, Sporotomaculum hydroxybenzoicum $\mathrm{BT}^{\mathrm{T}}$ (Brauman et al., 1998); 5, Cryptanaerobacter phenolicus LR7.2 ${ }^{\mathrm{T}}$ (Juteau et al., 2005). NR, Not reported. All strains have rod-shaped cells and none reduce nitrate.

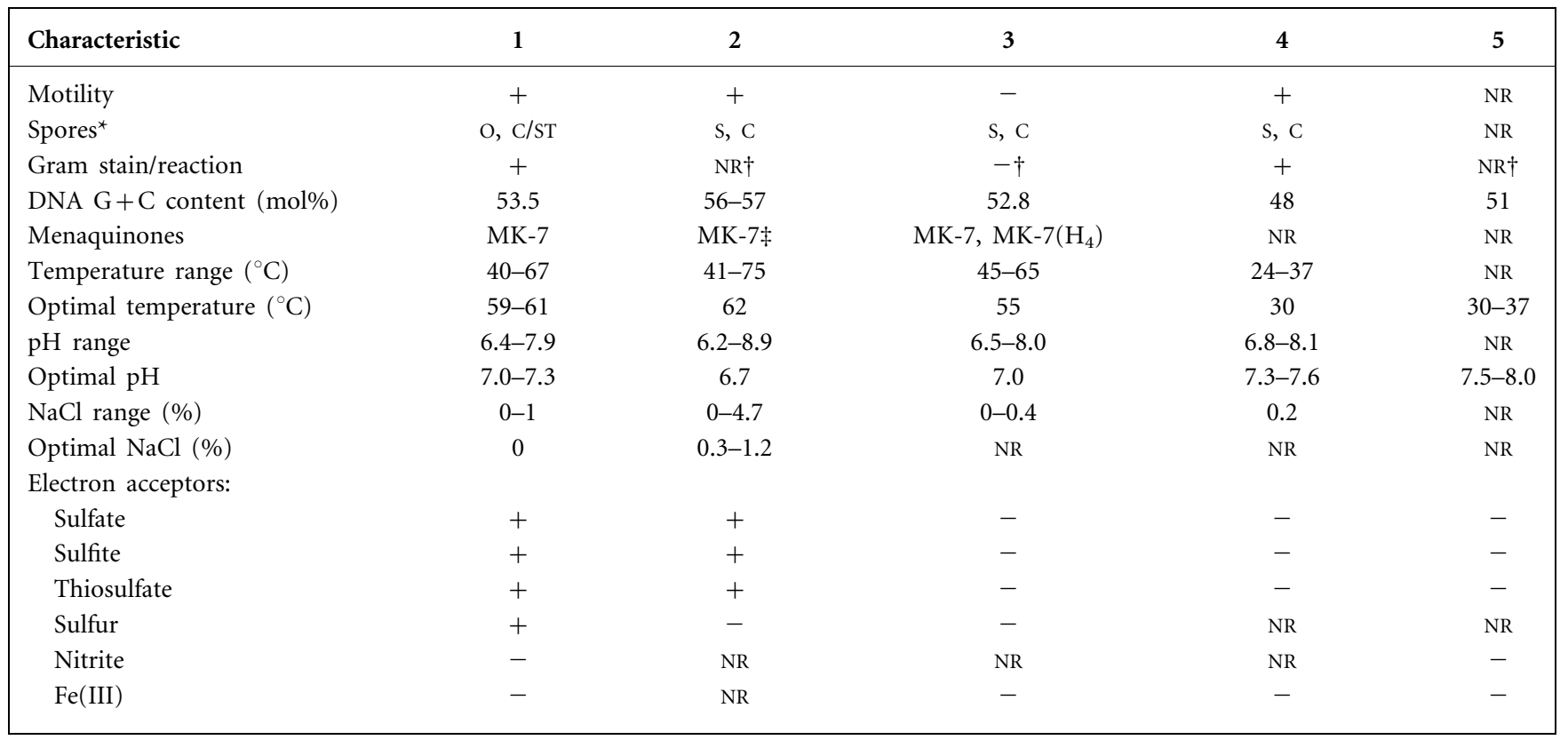

${ }^{\star} \mathrm{O}$, Oval; S, spherical; C, central; ST, subterminal.

$\nmid$ Gram-positive type cell wall observed by transmission electron microscopy.

¥Data from Imachi et al. (2002).

flagella and Gram-positive as determined by both Gram staining and the $\mathrm{KOH}$ test. The temperature, $\mathrm{pH}$ and $\mathrm{NaCl}$ ranges for growth of strain RA50E1 $1^{\mathrm{T}}$ are shown in Table 1. The operating temperature of the $\operatorname{FBR}\left(35^{\circ} \mathrm{C}\right)$ was lower than the minimum temperature required for growth of RA50E $1^{\mathrm{T}}$. Therefore, the strain was probably not active in the FBR, but rather survived as spores in the biofilm.

RA50E $1^{\mathrm{T}}$ was able to use sulfate, sulfite, thiosulfate and elemental sulfur as electron acceptors, but not nitrate, nitrite or iron(III). Electron donors utilized by RA50E1 ${ }^{\mathrm{T}}$ included $\mathrm{H}_{2} / \mathrm{CO}_{2}(80: 20, \mathrm{v} / \mathrm{v})$, lactate $(20 \mathrm{mM})$, formate, butyrate, isobutyrate, pentanoate, heptanoate, pyruvate, crotonate, mannose, glucose, fructose, myo-inositol, ethanol, propanol and butanol (each at $10 \mathrm{mM}$ ), pentanol and alanine (each at $5 \mathrm{mM}$ ), hexanoate and octanoate (each at $2 \mathrm{mM}$ ), decanoate, dodecanoate, tetradecanoate and hexadecanoate (each at $1 \mathrm{mM})$ and nonanoate $(0.5 \mathrm{mM})$. A number of electron donors (e.g. lactate, pyruvate, hexanoate, fructose, myoinositol, butanol and alanine) were oxidized incompletely to acetate, but no significant acetate production was observed during the sulfidogenic oxidation of octanoate and nonanoate. RA50E1 $1^{\mathrm{T}}$ did not utilize acetate, propionate, benzoate, malate, malonate, fumarate, succinate, tartrate, citrate, methanol, arabinose, xylose, sucrose, lactose, maltose, galactose, cellobiose, trehalose or glutamate (each at $10 \mathrm{mM}$ ), glycine $(5 \mathrm{mM})$ or 4 -hydroxybenzoate $(2 \mathrm{mM})$ as electron donors. RA50E $1^{\mathrm{T}}$ fermented lactate and pyruvate.

The cell wall of strain RA50E ${ }^{\mathrm{T}}$ contained meso-diaminopimelic acid and the major respiratory isoprenoid quinone was menaquinone MK-7. The whole-cell fatty acid composition of strain RA50E1 $1^{\mathrm{T}}$ is shown in Table 2 . Significant proportions of iso-branched saturated fatty acids were found, the major fatty acids being iso- $\mathrm{C}_{15: 0}$ and iso- $\mathrm{C}_{17: 0}$ (Table 2). Strain RA50E1 $1^{\mathrm{T}}$ contained larger amounts of iso- $\mathrm{C}_{17: 0}$ and less $\mathrm{C}_{16: 0}$ fatty acid than representatives of related genera (Table 2). Additionally, RA50E1 $1^{\mathrm{T}}$ contained iso- $\mathrm{C}_{15: 1}$, cyclopropane fatty acid $\left(\mathrm{C}_{17: 0} \mathrm{cyc}\right)$ and dimethyl acetals (DMA; iso-C15:0 DMA, $\mathrm{C}_{16: 0} \mathrm{DMA}$ and iso- $\mathrm{C}_{17: 0}$ DMA), which were not detected in the selected representatives of related genera (Table 2). The $\mathrm{G}+\mathrm{C}$ content of the total DNA of strain RA50E1 $1^{\mathrm{T}}$ was $53.5 \mathrm{~mol} \%$ (Table 1 ).

The $16 \mathrm{~S}$ rRNA gene of strain $\mathrm{RA} 50 \mathrm{E} 1^{\mathrm{T}}$ contained several regions of variable length that did not align well with sequences of related species and probably represent inserts. Based on 16S rRNA gene sequences, strain RA50E1 ${ }^{\mathrm{T}}$ was distantly related to representatives of the genera Desulfotomaculum, Pelotomaculum, Sporotomaculum and Cryptanaerobacter (Fig. 2). The closest relatives within these genera were Desulfotomaculum thermocisternum ST90 ${ }^{\mathrm{T}}$ (89.3\% $16 \mathrm{~S}$ 
Table 2. Whole-cell fatty acid compositions (\%) of strain RA50E $1^{\top}$ and related type strains

Strains: 1, RA50E1 ${ }^{\mathrm{T}}$; 2, Desulfotomaculum thermocisternum DSM $10259^{\mathrm{T}}$ (Imachi et al., 2002); 3, Pelotomaculum thermopropionicum $\mathrm{SI}^{\mathrm{T}}$ (Imachi et al., 2002); 4, Cryptanaerobacter phenolicus LR7. ${ }^{\mathrm{T}}$ (Juteau et al., 2005). DMA, Dimethyl acetal; c, cis isomer; cyc, cyclopropane.

\begin{tabular}{|c|c|c|c|c|}
\hline Fatty acid & 1 & 2 & 3 & 4 \\
\hline $\mathrm{C}_{14: 0}$ & 2.0 & 6.2 & 3.2 & 5.8 \\
\hline iso- $\mathrm{C}_{15: 1}$ & 4.1 & & & \\
\hline iso- $\mathrm{C}_{15: 0}$ & 54.4 & 63.3 & 76.4 & 13.7 \\
\hline anteiso- $\mathrm{C}_{15: 0}$ & & 3.9 & & 18.9 \\
\hline $\mathrm{C}_{15: 0}$ & & 3.9 & & 3.5 \\
\hline iso- $\mathrm{C}_{15: 0} \mathrm{DMA}$ & 2.5 & & & \\
\hline iso- $\mathrm{C}_{16: 0}$ & & 2.4 & & 7.5 \\
\hline $\mathrm{C}_{16: 1} \omega 7 c$ & 1.0 & & & \\
\hline $\mathrm{C}_{16: 1} \omega 9 c$ & & & & $13.7^{\star}$ \\
\hline $\mathrm{C}_{16: 0}$ & 3.2 & 10.4 & 10.7 & 12.5 \\
\hline $\mathrm{C}_{16: 0}$ DMA & 2.0 & & & \\
\hline iso- $\mathrm{C}_{17: 0}$ & 8.2 & & 2.9 & 5.7 \\
\hline Branched $C_{17: 0}$ & & 2.4 & & \\
\hline anteiso- $\mathrm{C}_{17: 0}$ & & & & 7.3 \\
\hline $\mathrm{C}_{17: 0} \mathrm{cyc}$ & 3.8 & & & \\
\hline iso- $\mathrm{C}_{17: 0}$ DMA & 2.9 & & & \\
\hline $\mathrm{C}_{18: 1} \omega 9 c$ & 1.2 & & & 4.6 \\
\hline $\mathrm{C}_{18: 0}$ & 0.3 & 2.4 & 6.7 & 4.2 \\
\hline
\end{tabular}

*Present as methyl ester $(7.8 \%)$ and dimethyl aldehyde (5.9\%) in the analysis.

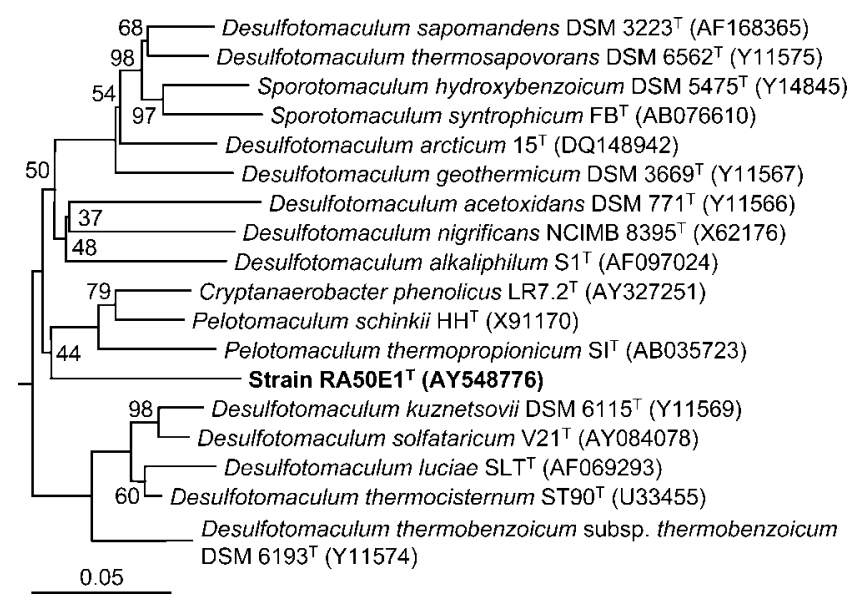

Fig. 2. Phylogenetic tree generated using distance matrix and neighbour-joining methods based on the 16S rRNA gene sequences of strain $\mathrm{RA} \mathrm{EE} 1^{\top}$ and related taxa. Archaeoglobus veneficus SNP6 ${ }^{\top}$ (GenBank accession no. Y10011) was used as outgroup (not shown). Numbers at nodes represent bootstrap percentages based on 1000 samplings. Bar, 0.05 changes per nucleotide position.
rRNA gene similarity in pairwise comparison using BioEdit), obligately syntrophic Pelotomaculum schinkii $\mathrm{HH}^{\mathrm{T}}$ $(88.7 \%)$, Sporotomaculum hydroxybenzoicum DSM $5475^{\mathrm{T}}$ $(85.1 \%)$ and Cryptanaerobacter phenolicus LR7.2 ${ }^{\mathrm{T}}(84.4 \%)$.

Strain RA50E1 ${ }^{\mathrm{T}}$ exhibited many features that are typical of members of the genera Desulfotomaculum and Pelotomaculum, such as rod-shaped, Gram-positive, spore-forming cells and MK-7 as the major menaquinone (Table 1). Members of the genus Pelotomaculum do not reduce sulfate, whereas the genus Desulfotomaculum harbours a collection of SRB that vary significantly with respect to their phylogeny and physiological capacities, such as complete against incomplete oxidation of substrates. Based on the phylogenetic tree (Fig. 2), there are species of the genus Desulfotomaculum that seem to be more divergent from each other than from the novel isolate or from representatives of the genera Pelotomaculum, Sporotomaculum and Cryptanaerobacter. Therefore, the genus Desulfotomaculum rather represents a 'supergenus' consisting of several 'subgenera'. Considering 16S rRNA gene sequencing, the genus Desulfotomaculum could be reclassified into several genera. On the basis of $16 \mathrm{~S}$ rRNA gene sequence data, strain RA50E $1^{\mathrm{T}}$ cannot be assigned to any genus with a validly published name. Based on its phylogenetic and phenotypic distinctiveness, it is proposed that strain $\mathrm{RA} 50 \mathrm{E} 1^{\mathrm{T}}$ represents a novel species in a new genus, for which the name Desulfurispora thermophila gen. nov., sp. nov. is proposed.

\section{Description of Desulfurispora gen. nov.}

Desulfurispora (De.sul.fu.ri.spo'ra. L. pref. de from; L. n. sulfur sulfur; Gr. fem. n. spora a seed and, in biology, a spore; N.L. fem. n. Desulfurispora a spore-forming organism that reduces sulfur compounds).

Cells are rod-shaped, spore-forming, Gram-positive, strictly anaerobic and thermophilic. Sulfate and other sulfur compounds are used as electron acceptors. Optimal growth occurs at neutral $\mathrm{pH}$. The cell wall contains meso-diaminopimelic acid and MK-7 is the major menaquinone. Major cellular fatty acids are iso- $\mathrm{C}_{15: 0}$ and iso- $\mathrm{C}_{17: 0}$. Phylogenetic position based on $16 \mathrm{~S}$ rRNA gene sequencing is in the Gram-positive bacteria. The type species is Desulfurispora thermophila.

\section{Description of Desulfurispora thermophila sp. nov.}

Desulfurispora thermophila (ther.mo.phi'la. Gr. fem. n. thermê heat; Gr. adj. philos loving; N.L. fem. adj. thermophila heat-loving).

In addition to the properties given in the description of the genus, the following properties are observed. Cells are motile and $0.6-1.0 \times 2.0-9.0 \mu \mathrm{m}$. Growth occurs at $40-$ $67^{\circ} \mathrm{C}$ (optimum 59-61 ${ }^{\circ} \mathrm{C}$ ), $\mathrm{pH}$ 6.4-7.9 (optimum pH 7.07.3 ) and $\mathrm{NaCl}$ concentration $0-1 \%$ (optimum $0 \% \mathrm{NaCl}$ ). Sulfate, sulfite, thiosulfate and elemental sulfur are used as electron acceptors, but nitrate, nitrite and iron(III) are not. 
Electron donors include $\mathrm{H}_{2} / \mathrm{CO}_{2}(80: 20$, v/v), lactate, formate, butyrate, isobutyrate, pentanoate, heptanoate, pyruvate, crotonate, mannose, glucose, fructose, myoinositol, ethanol, propanol, butanol, pentanol, alanine, hexanoate, octanoate, decanoate, dodecanoate, tetradecanoate, hexadecanoate and nonanoate. Fermentative growth occurs on lactate and pyruvate.

The type strain is RA50E1 ${ }^{\mathrm{T}}\left(=\mathrm{DSM} 16022^{\mathrm{T}}=\mathrm{JCM} 14018^{\mathrm{T}}\right)$, isolated from a sulfidogenic FBR treating acidic metalcontaining wastewater. The genomic DNA G $+C$ content of the type strain is $53.5 \mathrm{~mol} \%$ (as determined by HPLC).

\section{Acknowledgements}

This work was supported by the Finnish Funding Agency for Technology and Innovation, Outokumpu Oyj, Finland, the Finnish Graduate School in Environmental Science and Technology, the Academy of Finland and the European Commission (BioMinE contract 500329 and a grant for the DSMZ large scale facility). Annukka Hämäläinen, Esther Schüler, Anika Vester and Marlen Jando are acknowledged for technical assistance.

\section{References}

Altschul, S. F., Gish, W., Miller, W., Myers, E. W. \& Lipman, D. J. (1990). A basic local alignment search tool. J Mol Biol 215, 403-410.

Beeder, J., Torsvik, T. \& Lien, T. (1995). Thermodesulforhabdus norvegicus gen. nov., sp. nov., a novel thermophilic sulfate-reducing bacterium from oil field water. Arch Microbiol 164, 331-336.

Brauman, A., Müller, J. A., Garcia, J.-L., Brune, A. \& Schink, B. (1998). Fermentative degradation of 3-hydroxybenzoate in pure culture by a novel strictly anaerobic bacterium, Sporotomaculum hydroxybenzoicum gen. nov., sp. nov. Int J Syst Bacteriol 48, 215-221.

Campbell, L. L. \& Postgate, J. R. (1965). Classification of the sporeforming sulfate-reducing bacteria. Bacteriol Rev 29, 359-363.

Cashion, P., Holder-Franklin, M. A., McCully, J. \& Franklin, M. (1977). A rapid method for the base ratio determination of bacterial DNA. Anal Biochem 81, 461-466.

Collins, M. D. \& Jones, D. (1981). Distribution of isoprenoid quinone structural types in bacteria and their taxonomic implication. Microbiol Rev 45, 316-354.

Gregersen, T. (1978). Rapid method for distinction of Gramnegative from Gram-positive bacteria. Eur J Appl Microbiol Biotechnol $5,123-127$.

Groth, I., Schumann, P., Weiss, N., Martin, K. \& Rainey, F. A. (1996). Agrococcus jenensis gen. nov., sp. nov., a new genus of actinomycetes with diaminobutyric acid in the cell wall. Int J Syst Bacteriol 46, 234-239.

Heimbrook, M. E., Wang, W. L. L. \& Campbell, G. (1989). Staining bacterial flagella easily. J Clin Microbiol 27, 2612-2615.

Henry, E. A., Devereux, R., Maki, J. S., Gilmour, C. C., Woese, C. R., Mandelco, L., Schauder, R., Remsen, C. C. \& Mitchell, R. (1994). Thermodesulfovibrio yellowstonii, gen. nov. and sp. nov.: its phylogenetic relationship to Thermodesulfobacterium commune and their origins deep within the bacterial domain. Arch Microbiol 161, 62-69.

Imachi, H., Sekiguchi, Y., Kamagata, Y., Hanada, S., Ohashi, A. \& Harada, H. (2002). Pelotomaculum thermopropionicum gen. nov., sp. nov., an anaerobic, thermophilic, syntrophic propionateoxidizing bacterium. Int J Syst Evol Microbiol 52, 1729-1735.
Juteau, P., Côté, V., Duckett, M.-F., Beaudet, R., Lépine, F., Villemur, R. \& Bisaillon, J.-G. (2005). Cryptanaerobacter phenolicus gen. nov., sp. nov., an anaerobe that transforms phenol into benzoate via 4-hydroxybenzoate. Int J Syst Evol Microbiol 55, 245-250.

Kaksonen, A. H., Franzmann, P. D. \& Puhakka, J. A. (2003a). Performance and ethanol oxidation kinetics of a sulfate-reducing fluidized-bed reactor treating acidic metal-containing wastewater. Biodegradation 14, 207-217.

Kaksonen, A. H., Riekkola-Vanhanen, M.-L. \& Puhakka, J. A. (2003b). Optimization of metal sulphide precipitation in fluidizedbed treatment of acidic wastewater. Water Res 37, 255-266.

Kaksonen, A. H., Franzmann, P. D. \& Puhakka, J. A. (2004a). Effects of hydraulic retention time and sulfide toxicity on ethanol and acetate oxidation in sulfate-reducing metal-precipitating fluidizedbed reactor. Biotechnol Bioeng 86, 332-343.

Kaksonen, A. H., Plumb, J. J., Gibson, J. A. E., Franzmann, P. D. \& Puhakka, J. A. (2004b). Simple organic electron donors support diverse sulfate-reducing communities in fluidized-bed reactors treating acidic metal- and sulfate-containing wastewater. FEMS Microbiol Ecol 47, 279-289.

Kaksonen, A. H., Plumb, J. J., Robertson, W. J., Franzmann, P. D., Gibson, J. A. E. \& Puhakka, J. A. (2004c). Culturable diversity and community fatty acid profiling of sulfate-reducing fluidized-bed reactors treating acidic, metal-containing wastewater. Geomicrobiol J 21, 469-480.

Kaksonen, A. H., Plumb, J. J., Robertson, W. J., Spring, S., Schumann, P., Franzmann, P. D. \& Puhakka, J. A. (2006a). Novel thermophilic sulfate-reducing bacteria from a geothermally active underground mine in Japan. Appl Environ Microbiol 72, 3759-3762.

Kaksonen, A. H., Spring, S., Schumann, P., Kroppenstedt, R. M. \& Puhakka, J. A. (2006b). Desulfotomaculum thermosubterraneum sp. nov., a thermophilic sulfate-reducer isolated from an underground mine located in a geothermally active area. Int J Syst Evol Microbiol 56, 2603-2608.

Kaksonen, A. H., Spring, S., Schumann, P., Kroppenstedt, R. M. \& Puhakka, J. A. (2007). Desulfovirgula thermocuniculi gen. nov., sp. nov., a thermophilic sulfate-reducer isolated from a geothermal underground mine in Japan. Int J Syst Evol Microbiol 57, 98-102.

Kämpfer, P. \& Kroppenstedt, R. M. (1996). Numerical analysis of fatty acid patterns of coryneform bacteria and related taxa. Can J Microbiol 42, 989-1005.

Kroppenstedt, R. M. (1985). Fatty acid and menaquinone analysis of actinomycetes and related organisms. In Chemical Methods in Bacterial Systematics (SAS Technical Series, no. 20), pp. 173-179. Edited by M. Goodfellow \& D. E. Minnikin. London: Academic Press.

Mesbah, M., Premachandran, U. \& Whitman, W. B. (1989). Precise measurement of the $\mathrm{G}+\mathrm{C}$ content of deoxyribonucleic acid by highperformance liquid chromatography. Int J Syst Bacteriol 39, 159-167. Miller, L. T. (1982). Single derivatization method for routine analysis of bacterial whole-cell fatty acid methyl esters, including hydroxy acids. J Clin Microbiol 16, 584-586.

Monciardini, P., Cavaletti, L., Schumann, P., Rohde, M. \& Donadio, S. (2003). Conexibacter woesei gen. nov., sp. nov., a novel representative of a deep evolutionary line of descent within the class Actinobacteria. Int J Syst Evol Microbiol 53, 569-576.

Mori, K., Kim, H., Kakegawa, T. \& Hanada, S. (2003). A novel lineage of sulfate-reducing microorganisms: Thermodesulfobiaceae fam. nov., Thermodesulfobium narugense, gen. nov., sp. nov., a new thermophilic isolate from a hot spring. Extremophiles 7, 283-290.

Moussard, H., L'Haridon, S., Tindall, B. J., Banta, A., Schumann, P., Stackebrandt, E., Reysenbach, A.-L. \& Jeanthon, C. (2004). Thermodesulfatator indicus gen. nov., sp. nov., a novel thermophilic chemolithoautotrophic sulfate-reducing bacterium isolated from the Central Indian Ridge. Int J Syst Evol Microbiol 54, 227-233. 
Nilsen, R. K., Torsvik, T. \& Lien, T. (1996). Desulfotomaculum thermocisternum sp. nov., a sulfate reducer isolated from a hot North Sea oil reservoir. Int J Syst Bacteriol 46, 397-402.

Rhuland, L. E., Work, E., Denman, R. F. \& Hoare, D. S. (1955). The behaviour of the isomers of $\alpha, \varepsilon$-diaminopimelic acid on paper chromatograms. J Am Chem Soc 77, 4844-4846.

Sass, H., Overmann, J., Rütters, H., Babenzien, H.-D. \& Cypionka, H. (2004). Desulfosporomusa polytropa gen. nov., sp. nov., a novel sulfate-reducing bacterium from sediments of an oligotrophic lake. Arch Microbiol 182, 204-211.

Stackebrandt, E., Sproer, C., Rainey, F. A., Burghardt, J., Päuker, O. \&

Hippe, H. (1997). Phylogenetic analysis of the genus Desulfotomaculum: evidence for the misclassification of Desulfotomaculum guttoideum and description of Desulfotomaculum orientis as Desulfosporosinus orientis gen. nov., comb. nov. Int J Syst Bacteriol 47, 1134-1139.

Stookey, L. L. (1970). Ferrozine - a new spectrophotometric reagent for iron. Anal Chem 42, 779-781.

Tamaoka, J. \& Komagata, K. (1984). Determination of DNA base composition by reversed-phase high-performance liquid chromatography. FEMS Microbiol Lett 25, 125-128.

Zeikus, J. G., Dawson, M. A., Thompson, T. E., Ingvorsen, K. \& Hatchikian, E. C. (1983). Microbial ecology of volcanic sulphidogenesis: isolation and characterization of Thermodesulfobacterium commune gen. nov. and sp. nov. J Gen Microbiol 129, 1159-1169. 